\title{
PENGARUH VIDEO PEMBELAJARAN FISIKA TERHADAP PEMAHAMAN KONSEP SISWA SMP Yulisa $^{1}$, Lukman Hakim ${ }^{2}$, Linda Lia $^{3}$ \\ 1,2,3 Prodi Pendidikan Fisika, FKIP, Universitas PGRI Palembang 1yulisa_40@yahoo.com
}

\begin{abstract}
Abstrak
Kurangnya pemahaman konsep Fisika siswa berdampak pada rendahnya hasil belajar siswa. Penelitian ini bertujuan untuk mengetahui apakah ada pengaruh yang signifikan video pembelajaran Fisika terhadap pemahaman konsep siswa. Jenis penelitian yang digunakan adalah quasi eksperimen dengan desain the matching-only posttest-only control group design. Sampel dalam penelitian ini diambil dengan teknik purposive sampling dengan jumlah sampel 64 siswa yang terbagi menjadi dua kelas yaitu kelas VII 3 sebagai kelas eksperimen dan kelas VII 2 sebagai kelas kontrol. Pengumpulan data dilakukan dengan dokumentasi dan tes. Instrumen yang digunakan berupa tes pemahaman konsep dalam bentuk uraian. Berdasarkan hasil analisa data tes yaitu post-test menunjukkan thitung $>t_{\text {tabel }}(8,112>1,671)$ dimana terima $h_{\circ}$ jika $t_{\text {hitung }}<t_{\text {tabel }}$ dan terima $h_{a}$ jika $t_{\text {hitung }}>t_{\text {tabel }}$. Sehingga dapat disimpulkan bahwa video pembelajaran Fisika berpengaruh terhadap pemahaman konsep siswa kelas VII SMP Negeri 43 Palembang.
\end{abstract}

Kata kunci : video pembelajaran, Fisika, pemahaman konsep

(c) 2020 Pendidikan Fisika FKIP UPGRI Palembang

\section{PENDAHULUAN}

Pendidikan berperan penting dalam membentuk sikap dan kepribadian manusia. Melalui pendidikan manusia memperoleh ilmu pengetahuan dan pengalaman yang sangat berguna bagi kelangsungan hidupnya. Berbagai macam pembaharuan dalam aspek pendidikan dilakukan agar dapat meningkatkan kualitas pendidikan sehingga mampu mengarahkan dan membimbing ke arah kehidupan yang lebih baik, tidak hanya bagi diri sendiri melainkan juga bagi manusia lainnya.

Perkembangan ilmu pengetahuan yang sangat cepat dan pesat mengakibatkan pembelajaran IImu Pengetahuan Alam atau
Sains tidak cukup jika hanya bertujuan membekali materi sebanyak-banyaknya terhadap siswa. Kemajuan ilmu pengetahuan dan kompleksnya tingkat berpikir siswa, menuntut guru atau pendidik untuk menciptakan pembelajaran yang inovatif. Menurut Pujianto dkk (2013) Sains atau Fisika merupakan ilmu pengetahuan tentang gejala alam yang dituangkan berupa fakta, konsep, prinsip, dan hukum yang teruji kebenarannya dan melalui suatu rangkaian kegiatan. IImu Fisika memiliki peranan penting dan telah membantu mempermudah segala aktivitas kehidupan manusia (Lia, 2018). Jadi diharapkan siswa mampu memahami konsep, prinsip serta hukum-hukum kemudian diharapkan siswa 
mampu menyusun kembali dengan bahasanya sendiri sesauai dengan tigkat kemampuan intelektual yang dimilikinya.

Pemahaman (comprehension) menurut Sudijono (2008) adalah kemampuan seseorang untuk mengerti dan memahami sesuatu setelah sesuatu itu diketahui dan diingat. Adapun konsep menurut Sagala (2009) merupakan buah pemikiran seseorang atau sekelompok orang yang dinyatakan dalam definisi sehingga melahirkan produk pengetahuan meliputi prinsip, hukum, dan teori. Menurut Lisma dkk (2017) pemahaman konsep adalah kemampuan untuk mengerti dan memahami suatu konsep dan memaknai suatu materi dengan baik. Jadi pemahaman konsep merupakan kemampuan yang tidak hanya memahami tapi juga dapat menghubungkan pengetahuan awal dengan pengetahuan baru sehingga melahirkan produk pengetahuan meliputi prinsip, hukum, dan teori

Pembelajaran menurut Rusman (2012) pada hakikatnya merupakan suatu proses interaksi antara guru dengan siswa, baik interaksi secara langsung seperti kegiatan tatap muka maupun secara tidak langsung yaitu dengan mengunakan media pembelajaran. Menurut Fathurrohman (2015) pembelajaran adalah proses intraksi peseta didik dengan pendidik dan sumber belajar pada suatu lingkungan belajar. Jadi pembelajaran adalah proses belajar mengajar yang melibatkan peserta didik dan pendidik mengunakan suatu media.

Berdasarkan hasil pengamatan dan informasi yang diperoleh peneliti di SMP Negeri 43 Palembang pada semester ganjil tahun ajaran 2017/2018 bahwa rata-rata pemahaman konsep Fisika siswa masih tergolong rendah, khususnya pada materi pengukuran dilihat dari hasil ulangan Fisika siswa yang sangat rendah. Lebih dari $50 \%$ peserta didik kelas VII nilainya masih di bawah standar Kreteria Ketuntasan Minimal (KKM).

Rendahnya pemahaman konsep siswa disebabkan beberapa hal pertama, sekolah masih menerapkan pembelajaran langsung yang berpusat pada guru yakni guru menjelaskan materi kemudian memberikan contoh soal, lalu siswa mengerjakan beberapa latihan soal terkait materi yang diajarkan. Menurut Lisma dkk (2017) rendahnya kemampuan pemahaman konsep siswa disebabkan karena proses pembelajaran di dalam kelas yang masih menerapkan pembelajaran langsung.... Serta media yang digunakan guru tidak membuat siswa tertarik untuk belajar sehingga siswa merasa bosan, mengantuk, dan acuh untuk belajar Fisika. Penggunaan media pembelajaran merupakan hal sangat penting dalam proses pembelajaran Utami (2014) berpendapat agar pembelajaran Fisika lebih menarik diperlukan media pembelajaran yang lebih baik dan menarik yang diharapkan bisa membuat siswa lebih tertarik pada materi yang disampaikan oleh guru. Berdasarkan kedua masalah tersebut akibatnya siswa tidak memahami konsep-konsep Fisika sehingga berpengaruh terhadap hasil belajar siswa.

Media video dapat digunakan sebagai media pembelajaran yang efektif. Warsita (2008) mengatakan media video telah terbukti memiliki kemampuan yang efektif (lebih dari 70 $\%$ untuk menyampaikan informasi, hiburan, dan 
pendidikan). Menurut Munir (2012) video merupakan gambar yang bergerak. Menurut Sutarto dkk (2014) media pembelajaran video merupakan salah satu media pembelajaran dalam bentuk gambar yang bisa bergerak serta dilengkapi dengan suara untuk mempermudah penyampaian informasi. Jadi video adalah gambar bergerak yang dilengkapi dengan suara untuk mempermudah penyampaian informasi.

Menurut Sutarto dkk (2014) media video mempunyai daya tarik yang sangat tinggi, hal ini tidak terlepas dari sajiannya yang menampilkan video berupa gambar yang disertai suara, sehingga indera penglihatan dan pendengaran ikut terangsang. Media video akan memudahkan siswa dalam memahami konsep Fisika yang sedang dipelajarinya, sehingga media pembelajaran video dapat membuat siswa tertarik untuk belajar Fisika.

Menurut Peoples penggunaan media yang relevan akan menjadikan proses pembelajaran berlangsung efektif dan efisien dimana seluruh pengetahuan yang kita peroleh didapatkan dari $75 \%$ melihat, $13 \%$ dari mendengar dan $12 \%$ dari mengecap, mencium dan meraba (dalam Aqib 2013). Media pembelajaran merupakan alat bantu yang digunakan pendidik dalam proses pembelajaran agar pembelajaran lebih bermakna. Sejalan dengan pendapat Aqib (2013, hal. 49) mengatakan bahwa alat-alat bantu ini dimaksudkan untuk memberikan pengalaman lebih konkret, memotivasi, serta mempertinggi daya serap dan daya ingat siswa dalam belajar.

Rahmatul dkk (2015) mengungkapkan penggunaan media video mempermudah siswa dalam memahami konsep listrik statis sehingga terdapat pengaruh peningkatan yang siginifikan pada pemahaman siswa. Berdasarkan hasil analisis data diperoleh kelas eksperimen bahwa terdapat peningkatan yang signifikan antara rata-rata pretest dan posttest. Perbedaan dapat dilihat pada rata-rata posttest soal uraian sebesar 89,25 yang semula 65,75 .

Penelitian yang dilakukan Yunita dan Wijayanti (2017) menyatakan bahwa ada perbedaan yang sangat signifikan hasil belajar IPA siswa kelas VII SMP Negeri 1 Turi tahun pelajarann 2016/2017 antara yang diajar menggunakan media video dengan yang diajar tanpa menggunakan media video ditinjau dari keaktifan siswa. Berdasarkan data hasil penelitian uji anakova diperoleh hasil $F_{\text {hitung }}=$ 19,747 dengan $p=0,000$. Dari data tersebut diketahui $p \leq 0,01$. Jadi penggunaan media video dapat meningkatkan keaktifan siswa.

Menurut Adnyana (2013) berdasarkan hasil penelitiannya bahwa terjadi peningkatan pemahaman konsep kesetimbangan kimia siswa pada aspek macroskopis, mikroskopis, dan simbolis dengan besaran peningkatan yang bervariasi. Skor total yang diperoleh sebesar 68,08 pada siklus I dan 75,42 pada siklus II. Jadi penggunaan video dalam proses pembelajaran dapat meningkatkan pemahaman konsep siswa.

Wartono dkk (2017) berdasarkan hasil penelitiannya diperoleh bahwa penguasaan konsep siswa yang belajar dengan model interactive demonstration disertai video lebih tinggi dari pada siswa yang belajar dengan model interactive demonstration tanpa disertai video. Berdasarkan hasil analisis diperoleh hasil Qh > Qt $(155,03>2,86)$ sehingga model 
interactive demonstration disertai video berpengaruh terhadap pemahaman konsep siswa.

Berdasarkan latar belakang diatas, perlu dilakukan penelitian dengan judul "Pengaruh Video Pembelajaran Fisika Terhadap Pemahaman Konsep Siswa SMP Negeri 43 Palembang". Adapun tujuan dari penelitian ini adalah untuk mengetahui apakah ada pengaruh yang signifikan video pembelajaran Fisika terhadap pemahaman konsep siswa kelas VII SMP Negeri 43 Palembang.

\section{METODE}

Penelitian ini merupakan penelitian eksperimen yang bertujuan untuk mengetahui ada tidaknya pengaruh dari suatu perlakuan (intervensi). Metode penelitian yang digunakan dalam penelitian ini adalah metode quasi experimental design dengan mengunakan desain the matcing only post-test only control group design.

\begin{tabular}{llll}
\hline Treatment group & $M$ & $X$ & 0 \\
\cline { 2 - 4 } Control group & $M$ & $C$ & 0 \\
\hline
\end{tabular}

Gambar 1. The matcing only post-test only control group design (Sumber: Jack Fraenkel, Wallen Norman, Hyun Helen (2012))

\section{Keterangan:}

$\mathrm{M}=$ kelompok tidak dipilih secara random

$\mathrm{X}_{1}=$ perlakuan kelas eksperimen

$\mathrm{C}_{2}=$ kelas kontrol

$\mathrm{O}=$ nilai post-test

Pengambilan data sampel dengan cara teknik purposive sample. Sampel dalam penelitian ini sebanyak 62 orang siswa yang terdiri dari dua kelas, kelas VII3 sebagai kelas eksperimen dan kelas VII2 sebagai kelas kontrol masing-masing kelas berjumlah 32 siswa. Penelitian ini dilakukan pada semester ganjil tahun ajaran 2018/2019.

Data yang diperlukan dalam penelitian ini dikumpulkan melalui tes dan dokumentasi. Instrumen tes yang digunakan merupakan instrument berbentuk uraian yang sudah divalidasi dan sudah diuji cobakan.

Analisis data pemahamaan konsep siswa post-test diawali dengan menguji prasyarat analisis yaitu uji homogenitas menggunakan uji varians atau uji-F dan uji normalitas menggunakan rumus uji chi kuadrat. Kemudian, analisis data hasil tes akhir uji hipotesis dalam penelitian ini menggunakan uji-t (pihak kanan) dengan rumus Sudjana (2005), sebagai berikut.

$$
\begin{aligned}
& t=\frac{\bar{X}-\bar{X}}{s \sqrt{\frac{1}{n_{2}}+\frac{1}{n_{2}}}} \\
& \text { dengan, } \\
& s^{2}=\frac{\left(n_{1}-1\right) s_{1}^{2}+\left(n_{2}-1\right) s_{2}{ }^{2}}{n_{1}+n_{2}-2}
\end{aligned}
$$

Penelitian ini mengunakan video pembelajaran Fisika. Video merupakan gambar yang bergerak dan memiliki suara sehingga dapat memudahkan siswa dalam memahamai materi pembelajaran Fisika. Menurut Djamarah dan Zain (2010) kelebihan pengunaan video dalam proses pembelajaran diantaranya: (1) Dapat menstimulasi efek gerak; (2) Dapat diberi suara maupun warna; (3) Tidak memerlukan keahlian khusus dalam penyajiannya; (4) Tidak 


memerlukan ruangan gelap dalam
penyajiannya.

\section{HASIL DAN PEMBAHASAN}

\section{Hasil Post-Test}

Post-test yang diberikan kepada siswa baik pada kelas eksperimen maupaun kelas kontrol bertujuan untuk mengetahui pengaruh video pembelajaran Fisika terhadap pemahaman konsep siswa setelah di berikan perlakuan.

\section{Uji Normalitas}

Tabel 1. Hasil Uji Normalitas

\begin{tabular}{llllll}
\hline $\begin{array}{l}\text { Kelas } \\
\text { Ket }\end{array}$ & $\mathrm{X}_{\mathrm{h}}{ }^{2}$ & $\mathrm{dk}$ & $\mathrm{X}_{\mathrm{t}}{ }^{2}$ & Kesimpulan \\
\hline $\begin{array}{l}\text { Eksperi } \\
\text { men }\end{array}$ & 3 & $6-1=5$ & 11,070 & $\mathrm{X}_{\mathrm{h}}{ }^{2}<\mathrm{X}_{\mathrm{t}}^{2}$ \\
$\begin{array}{l}\text { Normal } \\
\text { Kontrol }\end{array}$ & 8 & $6-1=5$ & 11,070 & $\mathrm{X}_{\mathrm{h}}{ }^{2}<\mathrm{X}_{\mathrm{t}}^{2}$ \\
Normal & & & & \\
\hline
\end{tabular}

Berdasarkan tabel 1 menunjukan bahwa hasil analisis uji normalitas pemahaman konsep siswa kelas eksperimen dan kelas kontrol terdistribusi normal dimana $X_{h}{ }^{2}<X_{t}^{2}$. Sesuai criteria pengambilan keputusan, maka baik data kelas eksperimen mauapun data kelas kontrol terdistribusi normal.

\section{Uji Homogenitas}

Tabel 2. Hasil uji Homogenitas

\begin{tabular}{llll}
\hline Tes $F_{\text {hitung }} \quad \mathrm{dk}$ & $\mathrm{dk} \quad \mathrm{F}_{\text {tabel }}$ \\
Kesimpulan & \\
& pembilang penyebut \\
\hline
\end{tabular}

\begin{tabular}{llll}
\hline Post & & & \\
-test 1.18 & 31 & 31 & 1.84 \\
Homogen & & & \\
\hline
\end{tabular}

Pada tabel 2 di atas hasil analisis uji homogenitas kelas eksperimen dan kelas kontrol menunjukan bahwa $F_{\text {hitung }}<F_{\text {tabel }}$ atau $1.18<1.84$. Dengan kriteria Jika $F_{\text {hitung }} \leq F_{\text {tabel }}$ berarti homogeny, sehingga dapat disimpulkan bahawa data tersebut bersifat homogen.

\section{Nilai Rata-Rata}

Hasil post-test pemahaman konsep siswa kelas eksperimen dan kelas kontrol disajikan pada gambar 2 berikut.

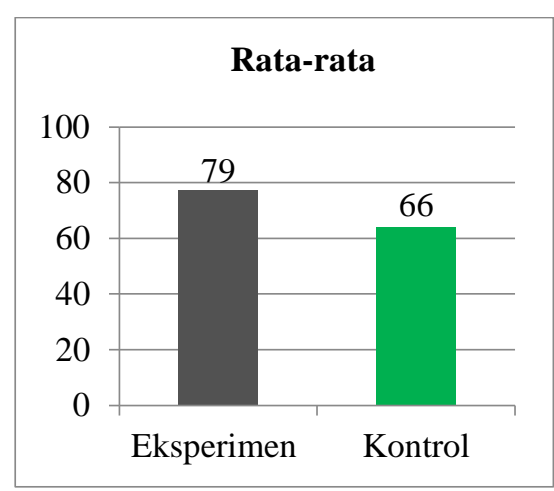

Gambar 2. Grafik nilai rata-rata pemahaman konsep Fisika siswa

Berdasarkan gambar 2 di atas bahwa nilai rata-rata kelas eksperimen lebih besar dari pada nilai rata-rata kelas kontrol. Nilai rata-rata yang dimiliki kelas eksperimen dan kelas kontrol memang tidak terlalu jauh memiliki perbedaan. Namun, meskipun demikian nilai tersebut sangat berpengaruh terhadap tujuan pembelajaran yang ingin akan dicapai.

\section{Uji Hipotesis}

Berdasrkan hasil uji normalitas dan uji hipotesis yang telah dilakukan, diperoleh data 
yang terdistribusi normal dan bersifat homogeny sehingga dapat dilanjutkan dengan uji hipotesis (uji pihak kanan). Hasil uji hipotesis data pemahaman konsep Fisika antara kelas ekperimen dan kelas kontrol ditunjukan pada tabel 3 berikut.

Tabel 3. Hasil Uji Hipotesis

\begin{tabular}{lllll}
\hline $\begin{array}{l}\text { Tes } \\
\text { Kesimpulan }\end{array}$ & $\mathrm{t}_{\text {hitung }}$ & $\mathrm{dk}$ & $\mathrm{t}_{\text {tabel }}$ & \\
\hline $\begin{array}{l}\text { Post-test } \\
\text { diterima }\end{array}$ & 8.112 & 62 & 1.671 & $\mathrm{H}_{\mathrm{a}}$ \\
\end{tabular}

Berdasarkan tabel 3 nilai $t_{\text {hitung }}>t_{\text {tabel }}$ atau $8,112>1,671$. Hal ini menunjukan bahwa ha diterima dan ho ditolak. Artinya bahwa ada pengaruh yang signifikan video pembelajaran Fisika berpengaruh terhadap pemahaman konsep siswa.

Penelitan ini bertujuan untuk mengetahui apakah ada pengaruh yang signifikan video pembelajaran Fisika terhadap pemahaman konsep siswa. Kegiatan pembelajaran dilakukan sebanyak 3 kali pertemuan terdiri dari 2 kali tatap muka dikelas dan 1 kali pertemuan untuk post-test baik pada kelas eksperimen maupun kelas kontrol. Tes akhir (post-test) diberikan untuk mengetahui hasil pemahaman konsep siswa setelah diberi perlakuan.

Nilai rata-rata post-test pemahaman konsep siswa pada kelas eksperimen adalah 79 dan pada kelas kontrol adalah 69. Berdasarkan data tersebut kemudian dilakukan uji normalitas, uji homogenitas dan uji hipotesis. Hasil uji hipotess menunjukkan bahwa $t_{\text {hitung }}>t_{\text {tabel }}(8,112$ $>1,671$ ) dimana terima $h_{\circ}$ jika $t_{\text {hitung }}<t_{\text {tabel }}$ dan terima $h_{a}$ jika $t_{\text {hitung }}>t_{\text {tabel }}$ karena $t_{\text {hitung }}>t_{\text {tabel }}$ maka $h_{a}$ diterima dan $h_{o}$ ditolak. Sehingga dapat disimpulkan bahwa video pembelajaran Fisika berpengaruh terhadap pemahaman konsep siswa.

Menurut Warsita (2008) media video telah terbukti memiliki kemampuan yang efektif (lebih dari $70 \%$ untuk menyampaikan informasi, hiburan, dan pendidikan). Ketertarikan siswa untuk mengikuti proses pembelajaran akan membantu siswa menerima materi yang disampaikan dan akan membantu siswa untuk lebih rajin belajar, sehingga pemahaman konsep siswa membaik. Perbedaan perlakuan pada langkah-langkah pembelajaran dan penyampaian materi dapat berpengaruh pada pemahaman konsep siswa. Penelitian yang dilakukan oleh Puspawati dkk (2013) menunjukan bahwa perbedaan perlakuan pada langkah-langkah pembelajaran dan proses penyampaian materi dapat mempengaruhi pemahaman konsep siswa.

Salah satu keunggulan penggunaan video yaitu dapat membuat siswa tidak merasa bosan untuk belajar dan lebih menarik perhatian siswa sehingga membuat siswa berkonsentrasi penuh terhadap video yang ditayangkan. Menurut Daryanto (2010) manfaat penggunaan media video pembelajaran akan membuat pesan yang disampikan menjadi lebih menarik perhatian, perhatian inilah yang penting dalam proses belajar, karena adanya perhatian akan timbul rangsangan atau motivasi belajar dan dapat membuat anak didik berkonsentrasi. Keadaan inilah yang memacu ingatan siswa lebih baik sehingga pada saat proses merangkum siswa berkonsentrsi penuh terhadap apa yang dipelajarinya. 
Menurut Istiqomah dkk (n.d.) media video yang hadir pada saat proses pembelajaran berlangsung, dapat membantu menyampaikan isi dan tujuan pembelajaran lebih cepat dibandingkan dengan kelas kontrol yang menggunakan model pembelajaran konvensional sehinga video berpengaruh terhadap pemahaman konsep siswa. Sutarto dkk (2014) mengatakan bahwa video mempunyai daya tarik yang sangat tinggi, hal ini tidak terlepas dari sajiannya yang menampilkan video berupa gambar yang disertai suara, sehingga indera penglihatan dan pendengaran ikut terangsang. Hal ini sejalan dengan hasil dalam penelitian ini bahwa ada pengaruh yang signifikan video pembelajaran Fisika terhadap pemahaman konsep siswa. Dengan demikian video pembelajaran khususnya materi pengukuran dapat menjadi media alternatife untuk digunakan dalam kegiatan pembelajaran.

\section{SIMPULAN DAN SARAN}

\section{Kesimpulan}

Berdasarkan hasil penelitian dan pembahasan dapat disimpulkan bahwa ada pengaruh yang signifikan video pembelajaran Fisika terhadap pemahaman konsep siswa kelas VII SMP Negeri 43 Palembang. Kriteria pengujian hipotesis yaitu, terima $h_{\circ}$ jika $t_{\text {hitung }}<$ $t_{\text {tabel }}$ dan terima $h_{a}$ jika $t_{\text {hitung }}>t_{\text {tabel }}$ karena $t_{\text {hitung }}>t_{\text {tabel }}$ atau 8,112 $>1,671$.Jadi $h_{a}$ diterima dan $h_{\circ}$ ditolak, sehingga video pembelajaran Fisika berpengaruh signifikan terhadap pemahaman konsep siswa kelas VII SMP Negeri 43 Palembang.

\section{Saran}

Adapun saran untuk penelitian lebih lanjut agar dapat dilaksanakan dengan baik dan lancar, terdapat beberapa hal yang perlu diperhatikan sebagai berikut:

1. Hendaknya selalu menyadari bahwa siswa sudah memiliki gagasan awal tentang suatu konsep tertentu sehingga menjadi pijakan bagi guru dalam merumuskan pembelajaran kedepannya

2. Kepada para peneliti yang akan melakukan penelitian yang sejenis, disarankan untuk meneliti mengunakan model pembelajaran yang lain untuk memperoleh hasil pemahaman konsep yang lebih baik lagi.

\section{DAFTAR PUSTAKA}

Adnyana, Gede Putra.(2013). Video Eksperimen dan Animasi Untuk Meningkatkan Pemahaman Konsep Kimia.Jurnal Pendidikan dan Pengajaran, Jilid 46, Nomor 3.hIm.266-277.

Aunnurrahman.(2010). Belajar dan

Pembelajaran. Bandung: Alfabeta

Aqib, Zainal. (2016). Model-Model, Media, dan

Strategi Pembelajaran Kontekstual (Inovatif). Bandung: Yrama Widya.

Daryanto. (2010). Media Pembelajaran. Yogyakarta: Gava Media.

Fathurrohman, Muhammad. (2015). ModelModel Pembelajaran Inovatif. Yogyakarta: Ar-Ruzz Media.

Fraenkel, Jack, R., Wallen, Norman, E., \&Hyun, Helen, H. (2012).How To Design And Evaluate Research In Education. Amerika: McGraw Hill. 
Istiqomah., dkk. (n.d). Pengaruh Penggunaan Media Video Terhadap Peningkatan Pemahaman Konsep Suhu dan Kalor Pada Siswa Kelas X Man 1 Palu.Jurnal Pendidikan Fisika Tadulako (JPFT). Vol. 5 No. 3.p-ISSN 2338 3240. e-ISSN 2580 5924.

Lia, Linda (2018). Kemampuan Mahasiswa

Dalam Membuat Alat Peraga Fisika Melalui Pembelajaran Berbasis Proyek. Wahana Didaktika. Vol.16 No.2.222-234.

Lisma dkk .(2017). Penerapan Model Learning

Cycle (LC) 7E Sebagai Upaya Peningkatan Pemahaman Konsep Aspek Menafsirkan dan Menyimpulkan Pada Materi Kalor Kelas X SMA.JIPF.Vol.2 .No.2. Hal 35-37. p-ISSN: 2477-5959. eISSN: 2477-8451.

Pujianto., dkk. (2013). Fisika Untuk SMA/MA

Kelas X Kurikulum 2013. Klaten: PT Intan Pariwara.

Puspawati., dkk. (2013). Pengaruh Model Pembelajaran Inkuiri Terbimbing Berbantuan Media Konkret Terhadap Pemahaman Konsep Ipa Siswa Kelas V Sd Gugus V Kecamatan Buleleng. Jurusan Pendidikan Guru Sekolah Dasar.FIP Universitas Pendidikan Ganesha Singaraja Indonesia.

Rahmatul., dkk. (2015). Video Terjadinya Petir Sebagai Media Pembelajaran Fisika
Untuk Meningkatkan Pemahaman Konsep Siswa pada Materi Listrik Statis.Prosiding Seminar Nasional Fisika.Vol IV. p-ISSN: 2339-0654. e-ISSN: 2476-9398.

Sutarto., dkk. (2014). Media Video Kejadian Fisika Dalam Pembelajaran Fisika Di SMA.Jurnal Pembelajaran Fisika. ISSN: 2301-9794.

Utami, Isti. (2014). Efektivitas Pemanfaatan Media Animasi Untuk Meningkatkan Motivasi Dan Hasil Belajar Fisika Siswa Madrasah Aliyah Negeri Wonosobo.Prosiding Pertemuan IImiah XXVIII HFI Jateng \& DIY, Yogyakarta. ISSN: 0853-0823.

Warsita, Bambang. (2008). Teknologi Pembelajaran Landasan dan Aplikasinya. Jakarta: Rineka Cipta.

Wartono., dkk. (2018). Penguasaan Konsep Fisika Disertai Video Dengan Menunggunakan Model Interactive Demonstration (Levels Of Inquiry). JFI.Vo.6 No.2. ISSN: p-ISSN: 2355-5785. e-ISSN: 2550-0325.

Yunita.,\& Wijayanti. (2017). Pengaruh Media Video Pembelajaran Terhadap Hasil Belajar IPA Ditinjau Dari Keaktifan Siswa. Jurnal LP3M Universitas Sarjanawiyata Tamansiswa Yogyakarta.Vol.3 No.2. 